Ewa Maria Marciniak*

\title{
Prolegomena do politologii jakościowej
}

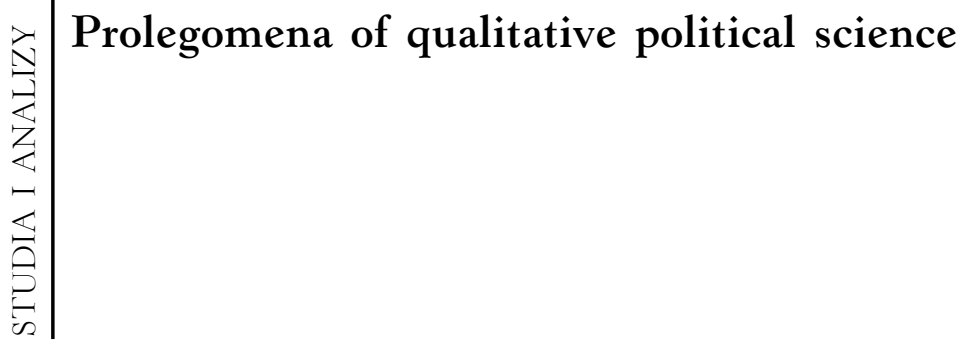

Stowa kluczowe: politologia jakościowa, epistemologia, symboliczny interakcjonizm, reguty badań jakościowych

Keywords: qualitative political science, epistemology, symbolic interactionism, rules of qualitative research

Abstrakt: Artykut ten jest głosem $w$ dyskusji na temat pluralizmu metodologicznego $w$ naukach o polityce, będacego rezultatem poszerzania przedmiotu badań politologicznych. Celem tego tekstu jest refleksja nad istota $i$ sensem badań jakościowych w politologii oraz identyfikacja regut, które moga i powinny towarzyszyć temu podejściu badawczemu. W rezultacie konceptualizowana jest idea politologii jakościowej.

Abstract: The topic of this article is methodological pluralism in political science, as a result of widening the scope of political science research. The objective is to reflect on qualitative research and to critically analyze its purpose and rules in political science. This article conceptualized the idea of qualitative political science.

* ORCID ID: https://orcid.org/0000-0001-7686-8509, doktor habilitowana nauk społecznych w zakresie nauk o polityce (2013), pracownik Wydziału Nauk Politycznych i Studiów Międzynarodowych Uniwersytetu Warszawskiego. W latach 2016-2019 dyrektor Instytutu Nauk Politycznych UW. Autorka publikacji naukowych na temat komunikacji politycznej, personalizacji polityki i zachowań wyborczych. członkini Polskiego Towarzystwa Komunikacji Społecznej oraz Komitetu Nauk Politycznych PAN. Członek Rady Programowej CBOS. E-mail: e.marciniak@uw.edu.pl 


\section{Wprowadzenie}

Politologia jakościowa jest obecna jako rezultat akceptacji pluralistycznych ujęć metodologicznych. David March i Gerry Stoker we wprowadzeniu do książki, traktującej o metodologii nauk o polityce odnosząc się do refleksji teoretyczno-metodologicznej z początku XXI wieku zaznaczają: „(...) politologia stała się dyscypliną bardziej różnorodną i o szerszych horyzontach"1. Autorzy ci zauważają też, że politologia nie jest tworzona przez mały klub ludzi myślących podobnie, lecz przez środowisko ludzi o różnych poglądach, którzy angażują się na rzecz lepszego rozumienia polityki ${ }^{2}$. Ow postulat jest aktualny kilkanaście lat późnej, bowiem nowe doświadczenia badawcze wzbogacają pole i metody badań, zachęcają do naukowej interakcji między badaczami, służącej rozwojowi kompetencji poznawczych i metodologicznych.

Artykuł ten jest głosem w dyskusji na temat zasadności obecności politologii jakościowej, co jest rezultatem poszerzania przedmiotu badań politologicznych. Celem tego tekstu jest refleksja nad istotą i sensem badań jakościowych, ich ramami epistemologicznymi oraz identyfikacja reguł, które mogą i powinny towarzyszyć temu podejściu badawczemu. Dualność stylu narracji w tym tekście jest związana z zadaniami, jakie sobie postawiłam: przybliżenie ram konceptualnych dla badań jakościowych oraz prakseologii procesu badawczego.

\section{Przedmiot badań politologii w zarysie}

Wiele obecnych w piśmiennictwie naukowym stanowisk odnośnie do przedmiotu badań politologicznych i samej nomenklatury może skutkować pewnym zamieszaniem poznawczym, które ma swoje dobre strony, ponieważ upoważnia do dyskusji systematyzujących, syntezujących lub odwrotnie analizujących wedle nowych kryteriów, zatem zamiast podsumowań i rekapitulacji mamy do czynienia z otwieraniem nowych pól badawczych. Określenie przedmiotu badań politologii stanowi punkt wyjścia do poszukiwania odpowiedzi na pytanie: jak badać ów przedmiot, jakie procedury obiektywizacji procesu poznania należy stosować, w jakim stopniu kongruencja przedmiotu badan i przyjętej metodologii

\footnotetext{
1 D. Marsch, G. Stocker, Wprowadzenie, [w:] D. Marsch, G. Stocker (red.), Teorie i metody w naukach politycznych, Kraków 2006, s. 3.

2 Tamże, s. 5.
} 
jest warunkiem sine qua non naukowości, którą można przypisać rezultatom badań?

Odpowiedź na pytanie ,jak” badać wymaga krótkiego wstępu na temat tego „co” współczesna nauka o polityce bada ${ }^{3}$. Wyrażam nadzieję, że można się zgodzić co do tego, że politologia jest nauką o polityce rozumianej jako działanie, jako znacząca obecność różnorodnych podmiotów w sferze polityki. Zasadniczo to tak określony przedmiot badań daje upoważnienie do testowania jakościowego podejścia w badaniach polityki. Tadeusz Klementewicz zabierając głos w kwestii rozumienia polityki, zakreśla pole badań politologicznych. Według niego politologia zajmuje się badaniem działań „różnych podmiotów sprawujących władzę, bądź starających się wpływać na jej wykorzystanie $(. . .)^{4}$. Jest też nauka o polityce gromadzeniem wiedzy „o formach kultury ('świadomości) ludzi uczestniczących w polityce, ideologiach, deklarowanych opcjach programowych partii, opinii publicznej, świadomości narodowej, klasowej, stereotypach, mitach rozpowszechnionych w danym społeczeństwie" ${ }^{\text {. }}$ T. Klementewicz nazywa również inne obszary badań politologicznych, nadając tym samym politologii walor dyscypliny badającej całościowo państwo z jego instytucjami w perspektywie historycznej, filozoficznej, czy strukturalno-funkcjonalnej. Sądzę zatem, że można przyjąć, iż istnieje równoważność perspektyw z których politolodzy badają państwo, system polityczny, instytucje polityczne, władzę, kulturę polityczną, zachowania wyborcze itp.

W związku z powyższym ukształtowała się tradycja badań konstruowanych wokół metodologii systemowej, instytucjonalnej, komparatystycznej, behawioralnej czy decyzyjnej6. Mając na uwadze tę swoistą wielobarwność przedmiotowo-metodologiczną, w tym artykule będę odsłaniała jedną z tych barw, rozumiejąc politologię jako naukę badającą sferę polityki, by nie powiedzieć „świat polityki” konstruowany przez działające w nim podmioty. Owo podmiotowe podejście do polityki rodzi

3 Piśmiennictwo na ten temat jest rozległe. Przytaczam jedynie niektóre propozycje. T. Żyro, Wstęp do politologii, Warszawa 2019, W. Jakubowski, Ł. Zamęcki, P. Załęski, Nauki o polityce. Zarys koncepcji dyscypliny, Pułtusk 2013, T. Klementewicz, Rozumienie polityki. Zarys metodologii nauki o polityce, Warszawa 2010.

4 T. Klementewicz, Rozumienie polityki. Zarys metodologii nauki o polityce, Warszawa 2010, s. 57.

5 Tamże, s. 59.

6 Szerzej: A. Chodubski, Wstęp do badań politologicznych, Gdańsk 2004. 
kluczowe pytanie, które brzmi: czego można się dowiedzieć o świecie polityki i poprzez jakie metody pozyskiwać o nim wiedzę.

Strefa przedmiotowego i metodologicznego komfortu, w której funkcjonują badacze niejednokrotnie wymaga przekroczenia. Politolog może implementować metody badań właściwe dla innych dyscyplin, ponieważ w nauce nie ma prawa własności, nikt nie zawłaszcza ani obszarów badań ani metod. Niejednokrotnie bycie „pomiędzy” jest twórcze i prowadzi (czasami niespodziewanie) do odkrywczych rezultatów. Zatem badacz-politolog jest wciąż w drodze, bywa, że buduje sobie pożądaną, bezpieczną intelektualną przystań, ale nie byłby badaczem z prawdziwego zdarzenia, gdyby nie cechował go twórczy niepokój.

\section{Badacz w drodze}

Poszukiwanie odpowiedzi na pytanie jak badać rzeczywistość polityczną w jej wielorakich aspektach wydaje się niezmiennie aktualne. Powodów jest sporo.

Po pierwsze - rzeczywistość polityczna jest dynamiczna, a to skutkuje tym, iż przedmiot badań politologii wciąż ulega zmianom. Jeśli na przykład dobrze rozpoznany jest sposób badania instytucji politycznych, to już złożone relacje między nimi wymagają innego namysłu. Jeśli dobrze rozpoznany jest sposób badania systemu politycznego, w tym partyjnego, to ich otoczenie - kulturowe, medialne wymaga wyjścia poza metodę systemową i włączenia np. badań osadzonych w antropologii komunikacji, etnografii czy analizie dyskursu.

Po drugie - poszczególne obiekty badań, o ile są względnie stałe (choć jest to też dyskusyjne), to z pewnością kontekst, w którym funkcjonują i mogą być badane, jest złożony i zmienny. Można powiedzieć, że „kontekst robi różnicę”. To potoczne określenie oznacza tyle, że kontekst wyznaczany przez osobistą historię życia osoby badanej, jej habitus, moment historyczny i związaną z nim ocenę ważności sytuacji politycznej, skutkuje uzyskaniem odmiennych interpretacji i konkluzji badawczych.

Po trzecie - badacze z różnymi indywidualnymi i kolektywnymi kulturami metodologicznymi wciąż poszukują dobrych dla siebie praktyk badawczych, niejednokrotnie odmiennych, które mogą być intelektualnym wyzwaniem. Odnosi się to również do badań zakotwiczonych w podejściu jakościowym. 


\section{Dwa podejścia - wyjaśnianie i rozumienie}

Kolejne lata przynoszą dominację określonych trendów metodologicznych. I tak w ostatnim czasie intensywnie rozwija się politologia „ilościowa” i związana z nią ilościowa analiza danych, co znajduje wyraz licznych badaniach w Polsce i na świecie. Nie oznacza to, że podejście jakościowe do badania zjawisk politycznych nie ma racji bytu. Dzieje się tak dlatego, że w naukach społecznych równoprawnie obecne są dwa podejścia, dwie filozofie rozumienia świata społecznego, w tym politycznego. Po pierwsze, zakłada się, że świat społeczny, w tym polityczny jest mierzalny, jest kwantyfikowalny - zatem zjawiska i procesy polityczne można i należy mierzyć za pomocą różnych narzędzi, a następnie - poprzez określone procedury statystyczne - wyjaśniać i na ich podstawie formułować różne predykcje. Mowa tu o wartości eksplanacyjnej i predykcyjnej badań ilościowych. Można też przyjąć, że świat społeczny, w tym polityczny jest konstruowany przez podmioty działające w sferze polityki - zatem zjawiska i procesy polityczne można i należy opisywać, interpretować, nadawać im znaczenia, stosując różnorodne narzędzia i techniki badawcze właściwe dla badań jakościowych. Oba podejścia należy traktować jako równoprawne, aczkolwiek sens ich stosowania zależy przede wszystkim od celu, jaki chcemy osiagnąć. W badaniach jakościowych kładzie się nacisk na rozumienie doświadczeń związanych z podejmowanymi działaniami, statusem, percepcją zjawisk politycznych czy procesów. Przy czym badanie rzeczywistości politycznej metodami „miękkimi” zakłada swoistą elastyczność, tj. w trakcie badań metody można zmienić, przekształcać po to, aby dostrzec w badanym zjawisku nieprzewidziane wcześniej aspekty. W tym przypadku zakłada się subiektywny charakter własnej wiedzy i każdego poznania. Dlatego też badania jakościowe i ich rezultaty nie dają możliwości prognozowania, nie można wyciagać na ich podstawie wniosków na temat związków między zmiennymi, ani dostrzegać prawidłowości. Mają one zatem zastosowanie, gdy celem badań jest zrozumienie subiektywnych doświadczeń i znaczeń, jakie badane podmioty im nadają.

\section{Politologia jakościowa}

Nie jest celem tego fragmentu artykułu przypominanie jakie narzędzia i techniki wykorzystywane są w badaniach jakościowych. Taką znakomitą prezentację, uwzględniającą nowe tendencje znaleźć można 
w książce pod redakcją Dariusza Jemielniaka ${ }^{7}$. Moim celem jest „uchwycenie" istoty badań jakościowych w politologii i w konsekwencji próba określenia, czym jest politologia jakościowa.

Przyznać trzeba, że wielu inspiracji w tym zakresie dostarcza piśmiennictwo na temat socjologii jakościowej ${ }^{8}$. Od wielu lat toczą się dyskusje socjologów, a ostatnio również psychologów na temat jakościowych metod badań w obrębie tych dyscyplin. Wyrazem tej dyskusji jest też czasopismo naukowe «Socjologia Jakościowa» oraz dyskusja naukowa na Uniwersytecie Wrocławskim, której inicjatorką jest Maria Straś-Romanowska. Dyskusja na temat psychologii jakościowej znalazła wyraz w publikacjach i konferencjach naukowych ${ }^{9}$. Na kanwie tych dyskusji w niniejszym tekście prezentuję swój głos w dyskusji o politologii jakościowej.

Każdy badacz potrzebuje zakotwiczenia w jakichś ramach konceptualnych, teoretycznych. Potrzebuje punktu odniesienia dla naukowego myślenia o polityce jako praktyce społecznej i sposobach jej badania. Zatem również rozważania na temat politologii jakościowej muszą być poprzedzone refleksją wokół możliwych ram epistemologicznych.

Liczba mnoga jest tu użyta nie bez kozery. Bowiem takie ramy może wyznaczać wiele nurtów interpretacjonistycznych i związanych z nimi metod i technik badawczych. Są to m.in. hermeneutyka, teoria ugruntowana, teoria konstruktów, analiza konwersacyjna, symboliczny interakcjonizm. Ten ostatni wydaje się nie tylko płodny intelektualnie, ale jednocześnie oddający ducha badań jakościowych w stopniu niemal wyczerpującym oraz sensownym z punktu widzenia politologa.

\section{Symboliczny interakcjonizm jako rama konceptualna badań jakościowych}

Mark Bevir i Roderick Rhodes podkreślają, że „interpretacjonistyczne podejścia do badań politologicznych skupiają się na znaczeniach, które określają kształt działań i instytucji, oraz na sposobach kształtowania tych działań i instytucji” ${ }^{10}$. Autorzy ci zaznaczają też, że stosunki mię-

7 D. Jemielniak, Badania jakościowe. Metody i narzędzia, t. 2, Warszawa 2012.

8 D. Jemielniak, Badania jakościowe..., K. Konecki, Studia z metodologii badań jakościowych. Teoria ugruntowana, Warszawa 2000.

9 M. Straś-Romanowska, O metodzie jakościowej w kontekście rozważań nad tożsamościa psychologii, [w:] M. Straś-Romanowska (red.), Metody jakościowe w psychologii wspótczesnej, Wrocław 2000, s. 24.

10 M. Bevir, R.A.V. Rhodes, Teoria interpretacjonistyczna, [w:] Teorie i metody..., s. 131. 
dzyludzkie nie są możliwe do zrozumienia jeśli nie rozumiemy wiążących się z nimi znaczeń ${ }^{11}$. To właśnie kategoria „znaczeń” nadawanych w wyniku interakcji społecznych będzie stanowić jeden z punktów odniesienia w dalszych rozważaniach. $\mathrm{Z}$ niezwykle bogatych treściowo założeń symbolicznego interakcjonizmu zaprezentuję też koncepcję „działań połączonych” i oczywiście koncepcję „symbolicznej interakcji”.

Symboliczny interakcjonizm zakłada, że świat społeczny (ale sądzę, że również i polityczny) jest nieustannie tworzony przez działające w nim podmioty (indywidualne i zbiorowe), a przez to subiektywny i zmienny. Podmioty, które działają w przestrzeni politycznej czynią fundamentem swoich działań wartości, przekonania i preferencje. Jeśli głosują na daną partię polityczną, to na ogół podzielają jej wartości, a ściślej ujmując te wartości, które partia eksponuje w swoim politycznym przekazie. Myśl ta nawiązuje do koncepcji H. Blumera, jednego z twórców symbolicznego interakcjonizmu, który podkreślał, że „czynności istot ludzkich w stosunku do rzeczy zasadzają się na znaczeniach, które te rzeczy mają dla nich.(...) Dodawał też, „że przypisywanie znaczeń do przedmiotów dokonuje się poprzez symbole i jest procesem ciągłym, a przypisywane znaczenia są wynikiem interakcji społecznych i mogą być modyfikowane poprzez proces interpretacyjny" ${ }^{12}$. Pojawiają się dwa kluczowe pojęcia interakcja i symbole.

„Interakcja jest możliwa, gdy jej uczestników łączy pewna wspólnota. Może być to np. wspólnota symboli podzielanych przez uczestniczące w interakcji podmioty, która umożliwia tworzenie jakichś stosunków i/lub korygowanie już istniejących. Innymi słowy działanie społeczne określonych podmiotów odznacza się w działaniu grupy podmiotów czy nawet całej wspólnoty"13.

Według H. Blumera „człowiek, żyjąc w świecie społecznym staje naprzeciw obiektów, wyposażonych w znaczenia, posiadających rozmaitą dla niego ważność. Jest to świat napotykany przez niego w sytuacjach działania. Określenie znaczenia sytuacji jest podstawowym procesem, w który osoba działająca jest aktywnie zaangażowana"14.

Uczestnictwo w polityce jest niewątpliwie taką blumerowską sytuacją działania, dla jednych istotną (nadawanie ważności) dla innych nieistotną (unieważnianie) w odniesieniu do tego uczestnictwa. Nadawanie znacze-

11 Tamże, s. 135.

12 A. Mattelart, M. Mattelart, Teorie komunikacji. Krótkie wprowadzenie, Warszawa-Kraków 2001, s. 103.

13 I. Krzemiński, Interakcjonizm symboliczny $i$ socjologia, Warszawa 1986, s. 52.

14 E. Hałas, Obywatelska socjologia szkoty chicagowskiej, Lublin 1994, s. 51. 
nia w jednym lub drugim kierunku dzieje się w toku interakcji społecznej, to ona jest źródłem znaczeń, które ulegają zmianom, są modyfikowane poprzez procesy interpretacyjne ${ }^{15}$. Interakcje społeczne stanowią o dynamice życia społecznego. Ich wielorakość i różnorodność jest kwintesencją funkcjonowania grup. Życie grupowe staje się procesualne, dzięki czemu ludzie wzajemnie modyfikują swoje zachowania. Te modyfikacje odnoszą się do różnych obszarów życia społecznego, w tym również politycznego - ludzie na przykład zmieniaja preferencje polityczne, czy przekonania na temat jakichś podmiotów polityki właśnie pod wpływem interakcji. A to oznacza, że interakcja jest otwarta na częściowe lub całościowe redefinicje, te zaś moga przyczyniać się do kształtowania się innych zachowań czy innych treściowo przekonań. Elżbieta Hałas podkreśla, że uczestnicy interakcji nie reagują na wymieniane przekazy symboliczne, ale interpretują je i - na podstawie tych interpretacji - konstruują własne koncepcje, będące podstawą działania każdego z nich ${ }^{16}$. Tym samym odrzucony jest na gruncie symbolicznego interakcjonizmu pogląd, że interakcję można rozumieć w kategoriach reaktywnych zachowań, czyli nierefleksyjnej odpowiedzi na obecność komunikacyjną jakiegoś podmiotu. Blumer właśnie interpretacji przyznaje kluczową rolę w procesach społecznych, odrzucając tym samym uproszczone rozumowanie przyczynowo-skutkowe ${ }^{17}$.

Przestrzeń publiczna jest wypełniona różnorodnymi interpretacjami wydarzeń, co oznacza, że to samo wydarzenie czy też decyzja władz np. w kwestii nowej polityki socjalnej może być interpretowana np. jako zapobieganie kryzysowi finansów publicznych lub jako działanie wymierzone przeciwko jakiejś grupie społecznej. Interpretacja nadaje znaczenia faktom. Tworzy system oceniania, wartościowania, jednoczy i dzieli społeczeństwo zwłaszcza wówczas gdy subiektywna początkowo interpretacja staje się podzielaną społecznie opinią na dany temat.

Twórcy symbolicznego interakcjonizmu podkreślali, że to nie fakty są źródłem nieporozumień, lecz ich interpretacje. Dodać trzeba, że rozumienie i interpretacja zdarzeń politycznych nie może być warunkowana jedynie zmiennymi demograficznymi. To nie wiek, płeć czy wykonywany zawód stanowią jedyną przesłankę ukształtowanych przekonań i preferencji politycznych. Takie stanowisko zajęliby badacze ilościowi. W przy-

15 Tamże, s. 61.

16 E. Hałas, Interakcja symboliczna a hermeneutyczna kategoria przedrozumienia, Warszawa 2003, s. 28, E. Hałas, Obywatelska socjologia..., s. 53.

17 E. Hałas, Obywatelska socjologia..., s. 47. 
padku badań inspirowanych podejściem interpretacjonistycznym należy dotrzeć do indywidualnych sposobów spostrzegania polityki, struktury motywacji wyborczych, nadawania znaczeń sytuacjom, zjawiskom czy wydarzeniom ${ }^{18}$.

W sferze publicznej funkcjonują różnorodne społeczne wyobrażenia na temat polityków i partii politycznych. Wyobrażenia te są często źródłem decyzji wyborczych. Niebagatelną rolę odgrywa zatem dotarcie do jądra tych wyobrażeń i ich interpretacji. Mowa tu nie tylko o wyobrażeniach jakie mają na temat polityków zwykli ludzie. Są to również wzajemne wyobrażenia o sobie aktorów politycznych, które zwłaszcza w sytuacji konfliktu politycznego, rywalizacji w kampanii wyborczej, czy w innych sytuacjach wymagających ekspozycji społecznej nadają sferze publicznej cech jakościowych. Politycy we wzajemnych interakcjach również tworzą obraz polityki.

Uczestnicy polityki - politycy i obywatele są zdolni do interakcji i rozumienia swoich poglądów, gdy stosują podobne schematy interpretacyjne. Ludzie interesują się polityką po „swojemu”. Rzadko obiektem zainteresowania są mechanizmy polityki, czy jej instytucjonalny wymiar. Owo indywidualne spostrzeganie wiąże politykę raczej z działalnością pozainstytucjonalną, nieodwołującą się do struktur i mechanizmów politycznych. W związku z tym politycy podejmują zabiegi interpretacyjne ukierunkowane na upraszczanie polityki i upodobnianie jej do sfery doświadczeń codziennych a czasami do sfery rozrywki, czyli do tego, co ludzie mogą zrozumieć a nawet polubić. Pojęcia i kategorie są raczej z kręgu potocznej, zdroworozsądkowej wiedzy. Metafory i porównania stosowane przez polityków przybliżają sferę polityki przeciętnemu odbiorcy. Dzięki tym zabiegom schematy interpretacyjne uczestników interakcji stają się podobne i tworzą podstawę do budowania wspólnoty znaczeń nadawanych zjawiskom, wydarzeniom dziejącym się w obszarze polityki. Zainteresowanie polityką rośnie ${ }^{19}$.

To rozprzestrzenianie własnych interpretacji, a wielokrotnie narzucanie jest dla H. Blumera wynikiem kolistej interakcji ${ }^{20}$. Koncepcja ta

18 Osoby przeze mnie badane udzieliły poparcia A. Dudzie, nie ze względu na poglądy polityczne czy orientację ideologiczną a dlatego, że w strukturze ich motywacji przeważyła negatywna ocena urzędników miejskich w Warszawie, co pośrednio przyczyniło się do przypisania R. Trzaskowskiemu negatywnych cech. Takiego stanu rzeczy nie uchwyciłyby badania ilościowe.

19 E.M. Marciniak, Komunikowanie polityczne w ujęciach interpretacyjnych, «Studia Politologiczne» 2013, vol. 25.

20 E. Hałas, Obywatelska socjologia szkoły chicagowskiej, Lublin 1994, s. 58. 
wyjaśnia proces tworzenia interpretacji rzeczywistości społecznej. Co prawda odnosi się głównie do sytuacji niepokoju społecznego, jednakże jej analiza pozwala na dostrzeżenie kilku uniwersalnych cech. „Kolista interakcja jest procesem wzajemnego wzmacniania swoich działań poprzez wielokrotne interakcje. Polega na wzajemnym stymulowaniu zachowań uczestników interakcji, którzy doprowadzają do jej wzmocnienia i ujednolicenia. Wzajemne interakcje subiektywnie postrzegających się jednostek i przypisujących wszystkiemu, co dookoła sobie tylko właściwą ocenę, prowadzą w bardzo dużym stopniu do nieprzewidywalnych przekształceń świata życia społecznego"21.

H. Blumer twierdzi, że kolista interakcja służy zdefiniowaniu spraw będących przedmiotem zainteresowania uczestników - rozwinięciu takich określeń jak przeciwnicy, osoby autorytetu, prawa indywidualne, praktyki instytucjonalne ${ }^{22}$. Rozprzestrzenianie i wytwarzanie znaczeń w wyniku kolistej interakcji jest ważnym i znaczącym procesem, którym interesuje się politolog jakościowy. Interakcje zachodzą w rozmaitych układach, w rodzinie, w miejscu pracy, grupie rówieśniczej23. Odgrywają one kształtującą rolę. Poprzez takie relacje społeczne kształtują się bowiem sądy i przekonania o polityce. Potoczne, zdroworozsądkowe, ale własne. Właśnie w wyniku tych codziennych interakcji aktualizowany jest stosunek do polityki, ustalana hierarchia problemów w „domowym” dyskursie politycznym. Z owego dyskursu wyłania się obraz polityki dominujący w społeczeństwie Znaczenia nabiera tutaj ogólna intelektualna i kulturowa kondycja społeczeństwa, a w jej efekcie sposób rozumienia rzeczywistości społecznej i politycznej.

Na koniec jeszcze jedna uwaga. Blumer nie sprowadza życia społecznego jedynie do interakcji codziennych na poziomie mikro. Wychodzi ze swoją koncepcją na wyższy poziom, dostrzegając zjawisko tzw. działań połączonych. Uważa on, że porządek społeczny wyłania się jako nowa forma działań połączonych, które odnoszą się do wspólnych form działania osób, organizacji czy instytucji. Jako przykład takiego działania podawana jest debata parlamentarna. Działania połączone wg H. Blumera tworzą regularne wzory, co znajduje odbicie w koncepcji kultury czy społecznego porządku. Jednakże „nawet te powtarzane działania muszą być tworzone na nowo. Jest to kluczowy punkt symboliczno-interakcyjnej

21 D. Staniszewski, Interakcjonizm symboliczny Herberta Blumera w ujeciu makrostrukturalnym, www.racjonalista.pl.

22 H. Blumer, Niepokój społeczny i protest zbiorowy, [w:] E. Hałas, Obywatelska socjologia szkoty chicagowskiej, Lublin 1994, s. 103-104.

23 E.M. Marciniak, Komunikowania polityczne... 
koncepcji działania społecznego. (...) H. Blumer ukazuje rolę symbolicznej interakcji zarówno dla utrzymania jak i zmiany znaczeń, które są podstawą działań społecznych - działań połączonych ${ }^{24}$. To oznacza, że symboliczny interakcjonizm proponuje nie tylko analizę małych form interakcyjnych, lecz także analizę organizacji czy instytucji, które funkcjonują, zmieniają się, kooperują czy konkurują w zależności od interpretacji, która zachodzi pomiędzy różnymi grupami - uczestnikami działań połączonych. Dzięki temu ramy konceptualne symbolicznego interakcjonizmu poszerzają się - od płaszczyzny codziennych interakcji do szerzej zakrojonych interakcji społecznych, w tym instytucjonalnych.

Przedstawiony tu zarys koncepcji symbolicznego interakcjonizmu może być swoistą intelektualną kotwicą dla badacza jakościowego. Dotyka bowiem tego poziomu życia społecznego, na którym są wytwarzane znaczenia polityki.

\section{Istota i fazy badań jakościowych w politologii}

Jak pisze Fiona Devine „metody jakościowe łączy się z epistemologią interpretacjonistyczną, która akcentuje dynamiczną, konstruowaną i zmienną naturę rzeczywistości społecznej”25. Cytowana autorka stoi na stanowisku, że badacze, którzy praktykują metody jakościowe koncentrują uwagę na świadomych aktorach społecznych, którzy przypisują swoim działaniom subiektywne znaczenie i interpretują sytuację swoją oraz innych ${ }^{26}$. Przyłączając się do tego stanowiska, chcę jednakowoż podkreślić, iż z powyższego nie należy wyprowadzać wniosku, że tylko „świadomy aktor społeczny” może być ciekawym obiektem badań. Należałoby w tym miejscu rozpocząć rozważania na temat owej świadomości, co nie jest moją intencją. Sądzę, że osoby badane cechuje zróżnicowany poziom autorefleksji („świadomości”), a zadanie badacza polega na docieraniu do istoty przekonań, motywacji, wartości czy rozumienia zjawisk i procesów. Innymi słowy nie ma żadnych wstępnych ograniczeń związanych z cechami społecznymi osób badanych. Uwe Flick przytacza za Normanem Denzinem pogląd, że badanie jakościowe jest usytuowaną aktywno-

24 E. Hałas, Obywatelska socjologia szkoty chicagowskiej, Lublin 1994, s. 56.

25 F. Devine, Metody jakościowe, [w:] D. Marsch, G. Stoker (red.), Teorie i metody w naukach spotecznych, Kraków 2006, s. 201.

26 Tamże, s. 201. 
ścią, która umieszcza obserwatora w świecie. Składa się z zespołu interpretatywnych i materialnych praktyk, które czynią świat widzialnym ${ }^{27}$.

W świetle powyższego jako właściwość badań jakościowych w politologii należy uznać docieranie do głębi zjawisk i procesów politycznych, tworzących sferę polityki, a także do ich kolektywnych i indywidualnych znaczeń, które tej sferze są nadawane. Badania jakościowe pozwalają również na dotarcie do realnych (a nie deklarowanych) postaw, sposobów rozumienia rzeczywistości politycznej i jej interpretacji przez badanych.

Klaryfikuje tę kwestię Krzysztof Konecki - znawca badań jakościowych w socjologii, który we wstępie do książki Davida Silvermana „Interpretacja danych jakościowych” podkreśla, że socjologia jakościowa nie sprowadza się wyłącznie do stosowania swoistych dla siebie metod badań. Jest to jakościowy sposób myślenia o ludzkim doświadczeniu, drogą naukowej oraz intersubiektywnej empatii, która pozwala dotrzeć do znaczenia doświadczeń indywidualnych i grupowych tak zwanego zewnętrznego świata ${ }^{28}$. Jakościowy sposób myślenia o doświadczaniu polityki przez jednostki i grupy może stanowić cechę politologii jakościowej.

Zadając pytania: jakie „to” jest?, po co „to” jest?, w jakim celu? odkrywa się sens polityki i działań aktorów politycznych, ujęty w kontekście biograficznym, ideologicznym czy pragmatycznym. Zainteresowanie kontekstem jest w tych badaniach szczególnie ważne. Przy czym nie chodzi tu o tzw. całościowy kontekst, bo taki nie daje się w pełni określić, lecz o jego różnorodne odmiany, choćby te wymienione powyżej. Badania interpretacyjne przynoszą w rezultacie nowe, czasami zaskakujące wyniki ${ }^{29}$. Problematyzują rzeczywistość, która wydawała się oczywista, stereotypowa, otwierają perspektywy poznawcze. I na tym polega ich zasadnicza wartość.

$\mathrm{Na}$ gruncie politologii sięgać można do specyficznych aspektów aktywności politycznej jednostek, docierając do ich indywidualnych motywacji usytuowanych $\mathrm{w}$ ich biografiach, orientacjach mentalnych, celach i wartościach oraz przekonaniach na temat aktorów politycznych

29 E.M. Marciniak, Komunikowanie polityczne... Przykład z wyborów prezydenckich 2020. Osoba badana: mężczyzna 45 lat, wysoki status społeczny, mieszkaniec dużego miasta, poglądy liberalne, tzw. typowy wyborca PO. W strukturze motywacji wyborczych na pierwszym miejscu znalazła się negatywna ocena TVN i skojarzenie tej stacji jako sympatyzującej z R. Trzaskowskim. Przeniesienie antypatii ze stacji telewizyjnej na kandydata w wyborach prezydenckich okazało się odkryciem również dla osoby badanej. 
i ich decyzji. Ma szansę powstać względnie holistyczny portret aktywnego obywatela, a wyniki badań mogą stanowić bazę do szerzej zakrojonych, reprezentatywnych procedur. Z kolei, gdy przedmiotem badania mogłaby być aktywność polityczna kobiet - to w tym zakresie ogląd dwóch zjawisk: marginalizacji i automarginalizacji przyczyniłby się do urealnienia znaczenia tego aspektu aktywności kobiet w sferze polityki. Politycy będący na politycznej emeryturze - jako osoby badane moga być źródłem wiedzy na temat obrazu przeciwnika politycznego i własnej roli w jego kreowaniu. Gdyby z kolei uczynić przedmiotem badania polityczną kulturę komunikacyjną, to można eksplorować kształtowanie się ofensywnych i defensywnych wzorców komunikowania politycznego, można też poszukiwać wzorów komunikowania o polityce na poziomie mikrospołecznym (codzienne rozmowy o polityce) w życiu rodzinnym, sąsiedzkim, zawodowym. Perspektywa interpretacyjna pozwoliłaby na zrozumienie ewolucji i doskonalenia kompetencji aktorów politycznych, autonomiczności vs zależności ich działań. Indywidualna percepcja różnych zjawisk (kryzysu klimatycznego, pandemii, bezrobocia) i ocena strategii podejmowanych przez polityków w tych sytuacjach może dać obraz nie zapośredniczonych przez media opinii i przekonań. Interpretacja i reinterpretacja debat telewizyjnych kandydatów na prezydenta, jakość relacji komunikacyjnych między podmiotami polityki, sens obecności medialnej byłych polityków (prezydentów, premierów, posłów) - to tylko niektóre pomysły na jakościowe badania w politologii.

F. Devine pisze, że słuchanie wyborców, którzy opisują jak podjęli decyzję o głosowaniu $\mathrm{w}$ istocie przyczynia się do odkrywania mechanizmów przyczynowych i sprzyja rozwojowi badań nad zachowaniami wyborczymi ${ }^{30}$.

Poprzez procedurę badawczą stosowaną w badaniach jakościowych i otwarte pytania oraz interpretacje uzyskuje się wgląd w niepowtarzalne, dynamiczne zdarzenie (zjawisko), mające swoją dramaturgię, formę, logikę i sens. Rozszyfrowanie tego zdarzenia i w konsekwencji jego zrozumienie wymaga, interpretacji, uwzględniającej zróżnicowane konteksty, ale także perspektywy, które wpływały na interpretacje.

Jest szansa na konstruowanie autentycznych, osobistych narracji politycznych i odpowiedź na pytanie: jaka jest naprawdę polityka. Wydaje się ona szczególnie ważna w sytuacji gdy świat polityki jest wykreowany i nasycony postprawdą.

30 F. Devine, Metody jakościowe, [w:] D. Marsch, G. Stoker (red.), Teorie i metody w naukach społecznych, Kraków 2006, s. 215. 


\section{Fazy badań jakościowych}

Każdy badacz po swojemu organizuje proces badawczy. Nie jest moim celem konstruowanie poradnika w tym zakresie. Jednakże zwrócenie uwagi na pewien zakres systematyzacji procesu badawczego może okazać się przydatne, zwłaszcza dla tych, którzy zaczynają badania jakościowe.

U. Flick szczegółowo wypowiedział się na temat przygotowania do prowadzenia badań jakościowych ${ }^{31}$. W książce tej znajduje się zdanie, że badania jakościowe nie wymagają takiego przygotowania jak badania ilościowe, choć powinny być planowane ${ }^{32}$. Wydaje się, że dobrze przemyślane i zaplanowane badania są kluczowym czynnikiem powodzenia. Interesującej perspektywy dostarcza w tym zakresie John Creswell ${ }^{33}$. Formułuje on tzw. listę kontrolną składającą się z 16 pytań, które mają ułatwić rzetelną procedurę badawczą. Na liście pytań znajdują się m.in.: pytania o konkretny typ strategii jakościowej, która będzie stosowana, czy badacz zna wcześniejsze zastosowania tej strategii, jest też pytanie o procedury rejestrowania informacji, jej kodowanie a także pytanie o podstawy interpretacji ${ }^{34}$.

Uwzględniając nowe tendencje w projektowaniu i prowadzeniu badań jakościowych proponuję, koncepcję czterech faz, które opisuję poprzez akronim PRPE, gdzie P - oznacza Preparation, R - Research, P - Publishing oraz E - Evaluation. Charakteryzując je krótko, wypada zaznaczyć, że przygotowanie (Preparation) do badań obejmuje przede wszystkim formułowanie problemów badawczych, jakie badacz chce rozwiązać, dobór metod i technik badań, wybór grupy osób badanych. Na tym etapie sformułowane pytania: „co” i „jak” chce zbadać organizuja proces badawczy. Cytowany U. Flick zwraca uwage na to, iż „W wielkim stopniu sukces badań zależy od jasno i dobitnie sformułowanego pytania badawczego. Przesądza ono, co jest ważne (jakie dane należy zebrać, jakie aspekty poddać analizie), a tym bardziej, co jest nieważne i powinno zostać pominięte (w bieżącym projekcie badawczym)"35. Oczywiście należy mieć na uwadze, że pytania badawcze mają charakter otwarty, mogą być modyfikowane w trakcie badań. Podejmowane czynności badawcze (Research) są clou tego procesu. Tu wykorzystuje się

31 U. Flick, Projektowanie badania jakościowego, Warszawa 2010, s. 17.

32 Tamże, s. 19.

33 J.W. Creswell, Projektowanie badań naukowych. Metody ilościowe, jakościowe i mieszane, Kraków 2013.

34 Tamże, s. 190.

35 U. Flick, Projektowanie badania jakościowego, Warszawa 2010, s. 51. 
dostępne metody zbierania danych. Mogą to być: wywiady indywidualne i grupowe, obserwacja uczestnicząca, badania etnograficzne, badania dokumentów, fotografii czy filmów. Opracowanie materiału badawczego następuje na ogół zgodnie z procedurą indukcyjną, tj. badacz tworzy kategorie, organizuje dane w coraz bardziej abstrakcyjne informacje ${ }^{36}$. Naturalną konsekwencją podjętych badań jest ich publikacja (Publishing). Tu zaznaczyć wypada tylko adekwatność treści artykułu naukowego do profilu czasopisma. Ważną kwestią są też kanały dotarcia do czytelników ${ }^{37}$. Ewaluacja (Evaluation) - to proces szacowania wartości podejmowanych badań, ich ocena. Faza ewaluacji jest jednocześnie fazą przygotowania do kolejnych badań. U. Flick używa pojęcia zarządzanie jakością w badaniach jakościowych ${ }^{38}$, co w swej istocie jest zbliżone do procesu ewaluacji. Szerzej na ten temat napiszę w kolejnej części artykułu.

\section{Reguły w politologii jakościowej}

Nie zgadzam się ze stanowiskiem, że badania jakościowe cechuje dowolność proceduralna. Cechuje je elastyczność, która nie jest równoznaczna z dowolnością. Poniżej przedstawiam trzy reguły badań jakościowych w politologii, ich katalog jest otwarty i może być wzbogacany dzięki kolejnym doświadczeniom badawczym. Jest to reguła przejrzystości, kontekstualności i otwartości badań.

\section{Reguła przejrzystości}

Andrew Moravscik w artykule Transparency: The Revolution in Qualitative Research, podkreśla, iz zgodnie z przyjętymi w 2014 r. przez American Political Science Association rekomendacjami badacze jakościowi powinni zwiększyć przejrzystość swoich badań poprzez stosowanie trzech zasad: przejrzystości danych (transparency date), przejrzystości analitycznej (analityc transparency) i przejrzystości produkcji (production transparency).

Przejrzystość danych to właściwie dostęp do danych, dający czytelnikowi szansę, aby poznał i docenił bogactwo źródeł, które wykorzystał

36 J.W. Creswell, Projektowanie badań naukowych, Kraków 2013, s. 191.

37 Pomijam kwestie, które w ostatnich latach nabrały szczególnego znaczenia, a są związane z miejscem publikacji i liczba punktów wydawnictwa czy periodyku naukowego.

38 U. Flick, Jakość w badaniach jakościowych, Warszawa 2011. 
badacz. Daje to też możliwość oceny czy zgromadzone dane zostały prawidłowo zinterpretowane. Moravscik pisze, że „we współczesnych jakościowych naukach politycznych próba zbadania krytycznych dowodów kończy się frustracją"39. Uważa też, że należy prezentować dane, których użyło się w celu poparcia swoich twierdzeń a także postuluje udostępnianie kontaktu z autorem. Zatem zwraca się uwagę na konieczność szerszego publikowania danych lub wyjaśnienie, dlaczego nie można tego zrobić.

Przejrzystość analityczna (analytic transparency) zapewnia czytelnikom dostęp do informacji o analizie danych: precyzyjnym procesie interpretacji zgodnie z którym autor wnioskuje, że dowody potwierdzają konkretne twierdzenie opisowe, interpretacyjne lub przyczynowe ${ }^{40}$. Można więc powiedzieć, że zadania badacza polega na objaśnianiu, w jaki sposób formułuje on wnioski z danych, ma być to klarowne wyjaśnienie, jakie są relacje między zgromadzonymi danymi a tym, co badacz wywnioskował.

Trzecim elementem tworzącym regułę przejrzystości jest przejrzystość produkcji - by użyć kalki językowej - co można rozumieć jako przejrzystość procesu przetwarzania materiału badawczego, której istotą jest to, że badacz prezentuje pełny opis procedur wykorzystywanych do gromadzenia lub generowania danych w sytuacji, gdy są to badania autorskie. A. Moravscik twierdzi, że „przejrzystość produkcji ma zapewnić czytelnikom dostęp do informacji o metodach wyboru poszczególnych zbiorów wykorzystywanych dowodów, argumentów i metod spośród innych możliwych wyborów" 41.

APSA zwraca uwagę, że istotnym problemem w politologicznych badaniach jakościowych jest ograniczona możliwość dostępu do materiału badawczego, który wykorzystuje badacz. Dlatego postuluje, aby w tekstach naukowych wykorzystywać tzw. aktywny cytat, to jest hiperłącze do oryginalnego źródła (badań własnych lub zastanych). Dzięki temu czytelnik ma szansę poznać materiał, na podstawie którego autor prowadzi wnioskowanie, czy interpretację $e^{42}$. Reguła przejrzystości sto-

39 A. Moravscik, Transparency: The Revolution in Qualitative Research, «Political Science \& Politics» 2014, vol. 47, s. 48.

40 Tamże, s. 52.

41 Tamże, s. 63.

42 Aktywny cytat czyli hiperlink, w którym jak pisze Andrew Moravscik stanowi dodatkowe źródło informacji o materiale badawczym, publikuje się ten link tylko wówczas, gdy publikowane wnioski są niejednoznaczne, kontrowersyjne, nieoczywiste i budzą wątpliwości samego badacza. Na marginesie można dodać, że taki aktywny link może stanowić tė̇ asumpt do dyskusji środowiskowych. 
sowana w politologicznych badaniach jakościowych wymusza niejako zwiększenie poziomu kooperacji miedzy badaczami, czy zespołami badawczymi, a także sięganie do innych konwencjonalnych form relacji np. mistrz-uczeń, autor-czytelnik.

Reguła autoewaluacji, refleksyjności - chodzi tu o podnoszenie jakości badań a także samoświadomość badacza jakościowego, kształtowaną w wyniku refleksji nad poszczególnymi etapami postępowania badawczego. Leszek Korporowicz ujmuje autoewaluację jako „zaproszenie do przyjęcia odpowiedzialności za własne działania”43. To refleksja będąca osobistym sposobem badania jakości swojej pracy badawczej. Badacz koncentruje się na poszukiwaniu atutów swojego badania a także słabego i najsłabszego ogniwa. Autoewaluacja daje odpowiedź na pytanie co należy zmienić, jak to zrobić i jakie to może przynieść rezultaty w przyszłości. Jest samoocenianiem prowadzącym do wyznaczania drogi badawczej. Odnosi się to do badań w ich poszczególnych fazach. Można mówić o fazach autoewaluacji, relewantnych do faz procesu badawczego, o których była mowa we wcześniejszym fragmencie tekstu. Oznacza to, że każda faza procesu badawczego podlega ponownemu namysłowi, potencjalnej weryfikacji i modyfikacji działań właściwych dla danej fazy. Choć w procesie autoewaluacji występuje dodatkowo jeszcze jedna faza, której nie mamy w badaniach właściwych. Jest to faza rekomendacji R (Recommendation). Odnoszą się one do działań, ewentualnych modyfikacji, które należy wdrożyć po zakończeniu badania. Rekomendacje są związane z jakością badań jakościowych ${ }^{44}$. U. Flick podejmuje kwestię szacowania jakości w badaniach jakościowych, zwracając uwagę na liczne dylematy w tym zakresie, związane choćby ze standaryzacją tych badań. Bo oto pojawia się pytanie, jak określić jakość tych badań w sposób właściwy, jaki jest związek między etyką badań a jakością ${ }^{45}$. Cytowany autor proponuje dyskusję w tym zakresie i na łamach książki formułuje różne rozstrzygnięcia.

$\mathrm{Na}$ kanwie dyskusji o ewaluacji w innych dyscyplinach badawczych i w sferze praktyk społecznych, chcę podkreślić, że ewaluacja jest szacowaniem wartości procesu poznawczego, która może być dokonywana przez środowisko naukowe, wszak pod warunkiem wznowienia/kontynuacji dyskusji w małych grupach badaczy. Autoewaluacja jest zaś

43 L. Korporowicz, Ewaluacja jako animacja. W kierunku ewaluacji piatej generacji, [w:]

G. Mazurkiewicz (red.), Ewaluacja w nadzorze pedagogicznym. Refleksje, Kraków 2011, s. 41.

44 U. Flick, Jakość w badaniach jakościowych, Warszawa, 2011, s. 11-14.

45 Tamże, s. 24-33. 
praktyką intelektualną pozwalającą na samodzielne dochodzenie do wniosków (rekomendacji), które należy odnieść do poszczególnych faz procesu badawczego. Wyłaniające się jako rezultat ewaluacji procedury badawcze, w tym metody mają charakter emergentny, tj. mogą pojawić nowe a nawet nieoczekiwane rezultaty, których nie było w podstawowym badaniu. Jest zatem szansa na powstanie nowych jakościowo własności poszczególnych faz badania, w tym interpretacji (rozumienia) wyników badań. Elastyczność jako cecha badań jakościowych może być ich siłą, zatem mogą one być efektem emergentnych procesów zachodzących w trakcie podjętej, rzetelnej ewaluacji. Warto też podkreślić, że autoewaluacja jest elementem profesjonalizacji praktyk badawczych i kształtuje kapitał metodologiczny badacza. W rozważaniach na temat autoewaluacji jako reguły w badaniach jakościowych nie sposób pominąć jeszcze jednego aspektu. Mowa tu o psychologicznej wartości autoewaluacji dla samego badacza. Na gruncie psychologii kognitywnej przyjmuje się, że człowiek jest autonomicznym, twórczym podmiotem zdolnym do kształtowania swoich kompetencji intelektualnych, motywacji i dojrzałości emocjonalnej. Akcentowana jest tu samowiedza, na którą składają się sądy opisowe, sądy wartościujące i sądy o standardach osobistych, które wyznaczają do jakiego stanu dążymy, jaki stan jest pożądany ${ }^{46}$. Jest więc ona podstawą rozwoju i konsekwentnego pogłębiania samoświadomości badacza. Jest to istotne zwłaszcza w badaniach jakościowych, w których relacja badacz-badany jest względnie bliska.

Reguła kontekstualności - Badania jakościowe są kontekstualne, co oznacza, że zjawiska bada się w ich społecznym (politycznym, ekonomicznym i kulturowym) kontekście, uwzględniając jego zróżnicowanie i dynamikę. J. Creswell podkreśla znaczenie naturalnego kontekstu, co oznacza, że osoby są badane w swoim codziennym środowisku. Badacz ten uznaje, że w hierarchii ważności cech badań jakościowych kontekst pozostaje na pierwszym miejscu ${ }^{47}$.

Zainteresowanie kontekstem wynika z faktu jego wpływu na badane zjawiska. Jak zauważa M. Straś-Romanowska celem badania interpretacyjnego jest rozpoznawanie zjawisk, wyodrębnienie ich z tła, przybliżenie ich przez zrozumiały, gwarantujący porozumienie opis, następnie zaś rekonstruowanie zachodzących między zjawiskami związków znaczeniowych, czyli przypisywanie im sensu ${ }^{48}$. Badania jakościowe pozwalają na

46 J. Kozielecki, Psychologiczna teoria samowiedzy, Warszawa 1986, s. 78.

47 J.W. Creswell, Projektowanie badań naukowych, Kraków 2013, s. 191.

48 M. Straś-Romanowska, O metodzie jakościowej w kontekście rozważań nad tożsamościa... 
ukazywanie zjawisk (np. wybory, kampania wyborcza) w nowych uaktualnionych kontekstach.

Reguła kontekstualności oznacza, że w badaniach jakościowych ujmuje się badane zjawiska w szerokim kontekście, co pozwala na dostrzeżenie różnych ich aspektów. Dzięki temu badacz uzyskuje obraz wieloaspektowy i wielowymiarowy. Dla badań politologicznych szczególne znaczenie ma kontekst ideologiczny, partyjny, instytucjonalny, organizacyjny ale także geograficzny, demograficzny, biograficzny.

Reguła otwartości - Badany jest informowany o prawdziwym celu badania, badacz działa jawnie, czyli informuje badanego o swoich intencjach, opisuje i wyjaśnia je adekwatnie do potrzeb osoby badanej. Nie prowadzi się badań z pozycji lepiej wiedzącego, traktuje się badanego jako kompetentnego współtwórcę wiedzy zdobywanej podczas badania, uznaje się równość kompetencji badanego i badacza. Przestrzeganiu reguły otwartości sprzyja znaczenie tematu badań dla osoby badanej. Devine zwraca w tym kontekście uwagę, że „to które problemy były uznawana za znaczące, za jak znaczące je uważali respondenci i w jaki sposób wypowiadali się na ich temat ściśle wiązało się z ich wcześniejszymi preferencjami politycznymi” 49 . To ważna konstatacja, z której wynika, że dopiero badania jakościowe pokazały nieoczywistość co do kierunku zmian preferencji politycznych. W cytowanym badaniu ta sama kwestia (podniesienie podatków) skłoniła jedną osobę badaną do podtrzymania poparcia (podatki „idą” na edukację) a drugą do zaniechania poparcia (wzrost podatków). Podatki okazały się interesującym tematem, wywołującym otwartą rozmowę badacza z osobami badanymi.

Poziom otwartości, gdy mowa na przykład o wywiadzie zależy od kategorii i pojęć jakimi posługuje się badacz. Postulat używania kategorii bliskich badanemu poznawczo i emocjonalnie, wydaje się oczywisty. Chodzi bowiem o to, by jak najwierniej uchwycić interpretacje problemu, który osoba badana przedstawia. Badacz zaś minimalizuje tendencje do narzucania własnej perspektywy i własnego aparatu kategorialnego. Choć jak zaznacza J. Creswell nie da się uniknąć odwołania się do „swoich wartości, sądów i osobistych uwarunkowań, takich jak płeć, historia, kultura, status społeczno-ekonomiczny, które mogą mieć wpływ na interpretacje formułowane w trakcie badania" ${ }^{50}$. Reguła otwartości zobowią-

49 F. Devine, Metody jakościowe, [w:] D. Marsch, G. Stoker (red.), Teorie i metody w naukach społecznych, Kraków 2006, s. 211.

50 J.W. Creswell, Projektowanie badań naukowych. Metody ilościowe, jakościowe i mieszane, Kraków 2013, s. 193. 
zuje, aby badanie traktować jako dwustronną, symetryczną relację, i, co istotne, wyniku której badacz nie może przewidzieć. Niekiedy sięga się do ponownego kontaktu z osobami badanymi, po to aby zweryfikować czy skonstruowane interpretacje oddają w rzeczywistości punkt widzenia osoby badanej. Otwartość oznacza też, że zmierza się do autentycznego i kompleksowego ujęcia perspektywy osób badanych, tak aby tworzone uogólnienia pochodziły z możliwe jak najbardziej niezafałszowanego doświadczenia badanych.

\section{Konkluzje}

Politologia jakościowa kształtuje się jako rezultat komplikacji pola polityki i wzrastającego znaczenia polityki w życiu obywateli. Co prawda wiele badań naukowych i sondażowych wskazuje, że ludzie w małym stopniu interesują się polityką, lub jedynie jej aspektami, jednak nie jest to do końca prawdziwy obraz. Polityka emocjonuje ludzi, łączy i dzieli, aktywizuje, upodmiotawia i alienuje. Jest też przedmiotem codziennych sporów toczonych realnie i wirtualnie.

Wielość tych doświadczeń odnosi się do indywidualnego poziomu, do relacji - jednostka-polityka. Treścią tych relacji są kwestie z obszaru osobistych ważności - utylitarnych (ceny gazu, prądu, zanieczyszczenie powietrza, problemy lokalne, drogi, szkoły, ceny biletów) oraz symbolicznych (prawa i wolności człowieka, sprawiedliwość, godność, wolność, podmiotowość). Jeśli prowadzący badania jakościowe politolog ma szansę na rozpoznanie sposobu, w jaki ludzie tworzą mikropolityczny świat wokół siebie, jak go nazywają i jak się w nim sytuują, to z tej szansy powinien korzystać.

Politologia jakościowa jest zasadna tam gdzie zjawiska są złożone treściowo oraz znaczeniowo, wieloznaczne i zmienne. Ich badanie pozwala na dotarcie do procesów myślowych i indywidualnych narracji, które konstruują ludzie, do interpretacji i znaczenia nadawanego tym zjawiskom. Analiza subiektywnych politycznych doświadczeń i subiektywnych znaczeń jest możliwa, gdy osoby badane mają szansę przedstawić własne rozumienie i interpretację „swoich” politycznych zdarzeń, swoich interakcji. Bo ich perspektywa jest ważniejsza od perspektywy badacza. W rezultacie dyskusji i refleksji, które wywołują zdarzenia polityczne czy wypowiedzi polityków, ludzie rozwijają sposoby widzenia świata polityki, który ich dotyczy i którym się interesują. Kształtuje się także poczucie własnego miejsca w tych zdarzeniach, które politolodzy powinni 
badać. Interakcje mają zatem charakter definiujący, w tym sensie, że ludzie w ich wyniku tworzą konkretne określenia i pojęcia tego, czego doświadczają, ustosunkowują się do rzeczywistości, w której działają. Tak tworzy się i ugruntowuje określony obraz polityki i polityków - najpierw osobisty, subiektywny, a jednocześnie z potencjałem intersubiektywności i transsubiektywności. Interpretacje polityki będące wynikiem interakcji rozszerzają i pogłębiają definicje polityki, prowadząc do jej akceptacji vs odrzucenia, ponieważ działania polityków mogą być interpretowane jako budzące sprzeciw, kontrowersje czy też jako zgodne z interesami ludzi. To na poziomie praktyki politycznej. Na poziomie refleksji teoretycznej pojawia się zadanie dla politologii jakościowej - jest nim badanie tych jednostkowych, niepowtarzalnych doświadczeń, ich interpretacja, umożliwiająca aktualizowanie naukowego rozumienia polityki.

\section{Bibliografia}

Chodubski A., Wstęp do badań politologicznych, Gdańsk 2004.

Creswell J.W., Projektowanie badan naukowych. Metody jakościowe, ilościowe i mieszane, Kraków 2013.

Flick U., Projektowanie badania jakościowego, Warszawa 2010.

Flick U., Jakość w badaniach jakościowych, Warszawa 2011.

Hałas E., Obywatelska socjologia szkoty chicagowskiej, Lublin 1994.

Jakubowski W., Zamęcki Ł., Załęski P., Nauki o polityce. Zarys koncepcji dyscypliny, Pułtusk 2013.

Jemielniak D., Badania jakościowe. Metody i narzędzia, t. 2, Warszawa 2012.

Klementewicz T., Rozumienie polityki, Zarys metodologii nauki o polityce, Warszawa 2010.

Konecki K.T., Wprowadzenie do polskiego wydania, D. Silverman, Interpretacja danych jakościowych, Warszawa 2007.

Korporowicz L., Ewaluacja jako animacja. W kierunku ewaluacji piatej generacji, https://ruj. uj.edu.pl/xmlui/bitstream/handle/item/74164/korporowicz_ewaluacja_jako_animacja_2011.pdf? sequence $=1$ \&isAllowed $=\mathrm{y}($ sierpień 2020).

Mazurkiewicz G., (red.), Ewaluacja w nadzorze pedagogicznym. Refleksje, Kraków 2011.

Kozielecki J., Psychologiczna teoria samowiedzy, Warszawa 1986.

Krzemiński I, Interakcjonizm symboliczny $i$ socjologia, Warszawa 1986.

Marciniak E.M., Komunikowanie polityczne w ujęciach interpretacyjnych, «Studia Politologiczne» 2013, vol. 25.

Mattelart A., Mattelart M., Teorie komunikacji. Krótkie wprowadzenie, Warszawa-Kraków 2001.

Marsch D., Stocker G., (red.), Teorie i metody w naukach politycznych, Kraków 2006.

Moravscik A., Transparency: The Revolution in Qualitative Research, «Political Science \& Politics» 2014, vol. (47).

Staniszewski D., Interakcjonizm symboliczny Herberta Blumera w ujęciu makrostrukturalnym, www.racjonalista.pl (sierpién 2020).

Straś-Romanowska M., Metody jakościowe w psychologii wspótczesnej, Wrocław 2000. 